\title{
Professionals and Technicians for Industry 4.0
}

\author{
Elmi Achelia, Indri Juwita Asmara, and Nani Grace Berliana
}

\begin{abstract}
Industry 4.0 is a new era of industrial revolution that is happening all over the world. Changes in a way of production and products builds new structure of labour markets, so that discussion of human resources is one of the concerns in Industry 4.0. Indonesia, with the potential from bonus demographics, needs to anticipate the impacts of changes that will likely occur. Industry 4.0 challenges the competition for advancing the technology and innovation, so that skilled workers with competency will be needed. Human resources, which are closely related to the development of science and technology and innovation, regarded as Human Resources in Science and Technology (HRST), including professionals and technicians. In this article, anticipated impact Industry 4.0 was studied, focused to professionals and technicians in Indonesia. To be able to have a positive impact on the new environment of Industry 4.0, increasing the number of professionals and technicians needs, in line with skills and competencies.
\end{abstract}

Index Terms-Hrst, professional, technician, industry 4.0, education.

\section{INTRODUCTION}

Industry 4.0 is a new era of industrial revolution that is happening globally and concurrently nowadays, since it has been recognized in 2011 as Germany's government initiative to become global leader of technological innovation. The majority of enterprises in major countries treat industry 4.0 as an opportunity, and realized to set up the preparation [1].

Industry 4.0 is characterized by changes in industrial processes and products, which gives impact to changing structure of the labour market, new skills and competencies demand, as well as emerging policy challenges [2]. Digital transformation changes the way resources are managed in the production process, with the implementation of IoT, cloud computing, artificial intelligence, robotics, and big data analytics. Therefore, in facing the industrial revolution, innovation and technology plays an important role and determine the productivity and competitiveness of a company, or a country in macro view.

Difference to the first industrial revolution's characteristic of mechanization in production, which then continued with the mass production and assembly line in the second industrial revolution, the fourth industrial revolution complemented computer and automation in the third industrial revolution with cyber physical systems [3]. More jobs will be created to develop and optimize cyber physical systems, counterintuitive with notion that automation in industry that might need less human labor. Hence, the increases in

Manuscript received Feburary 15, 2019; revised July 1, 2019.

The authors are with Center of Science and Technology Development Studies, Indonesia Institute of Science (LIPI), Indonesia (e-mail: elmiachelia@gmail.com, nani.grace@gmail.com). productivity should create new markets, new businesses, and new factories that increase demand for skilled labor.

Indonesia as a developing country with potential resources, both human and natural resources, needs to be prepared to be able to have competitiveness in the era of Industry 4.0. Indonesia's government through Ministry of Industry has initiate roadmap to catch up with it and determine focus in five sector, i.e. automotive, electronics, textile, food and beverage, and chemicals [4]. In response to the challenges of industry 4.0, the government began in directing priority steps to reform material flow, redesign industrial zones, embrace sustainability, empower SMEs, build nationwide digital infrastructure, attract foreign investments, upgrade human capital, establish innovation ecosystem, incentivize technology investment, and reoptimize regulations and policies. The government believes that being able to face Industry 4.0 challenges will give positive impact on economic growth and the creation of wider employment opportunities. One of the concerns is that Indonesia is in a demographic bonus period until year 2030, which means that there are large numbers of productive age population. This can means opportunities or threat, Volek \& Novotna stated that Industry 4.0 will cut labor by factory automation and on the other hand requires new workers with new skills[5]. This problem shows that it needs to be studied the impacts of Industry 4.0 implementation on Indonesia's labour market in preparation for the arrival of a new era of industry.

This chapter outline in general the incoming of Industry 4.0 and how Indonesia need to prepare to step ahead to Industry 4.0. The next section, we explain data sources and methodology used in overall discussion within this article. Later in section 3, we focus to illustrate Professional and Technician, considered as main occupation, to be involved in Industry 4.0. Next in section 4, we describe the education initiatives to develop human resources capability in facing Industry 4.0. Last in section 5, we discuss and draw some conclusions.

\section{DATA AND METHODOLOGY}

The objective of this article is to assess the anticipated impacts in facing the Industry 4.0 on Indonesia's labour market. This paper focuses on assessment in workforce based on job position as professionals and technicians as demand side. And higher education graduate, includes vocational education and university level education, as supply side.

Data source used is national labor survey from Indonesia's Statistical Office. The observed data were from periode 2005 to 2014. We also use higher education graduates from Ministry of Research, Technology, and Higher Education, from year 2002 to 2016.

Based on Indonesia's National Classification of 
Occupation, as is in International Standard Classification of Occupations (ISCO), the workforce job position consist of legislators, senior officials and managers, professionals, technicians and associate professionals, clerks, service workers and shop and market sales workers, skilled agricultural and fishery workers, craft and related trades workers, plant and machine operators and assemblers, elementary occupations, and armed forces.

The workforce is also seen in the Human Resources in Science and Technology (HRST) framework which intersect among them. Based on the definition proposed in Canberra Manual, Human Resources in Science and Technology includes people who have completed third-level education in the field of science and technology (based on ISCED) and or people who employed in S\&T occupation where the above qualifications are normally required (based on ISCO) [6]. HRST on education comprises ISCED category 5, 6, and 7 on 7 S\&T fields of study, i.e. natural sciences, engineering and technology, medical sciences, agricultural sciences, social science, humanities, other fields [7]. People working in ISCO major group 1, 2, and 3 can be considered HRST. HRST in major group 3 is "Technicians and associate professionals", includes subgroups $31,32,33,34$. And HRST in major group 2 is "Professionals", includes subgroups 21, 22, 23, 24. In addition to ISCO groups 2 and 3, some HRST-relevant occupations may be identified in major group 1 ("Legislators, Senior Officials and Managers") on three subgroups, i.e. "Production and Operations Department Managers" (subgroup 122), "Other Department Managers" (subgroup 123), which includes R\&D managers among others, and "General Managers" (subgroup 131). Indonesia's HRST is defined by mapping the appropriate national classification used in Indonesia, i.e. ISCO mapped to the Indonesian Standard Classification of Occupation named Klasifikasi Baku Jabatan Indonesia (KBJI) and ISCED reference on Indonesian education system. Based on that, Indonesia's HRST are people who graduated from 3-years Diploma or higher in the field of science and technology, and / or those who work in positions as specified in KBJI [8].

\section{RESULT}

\section{A. Current Condition on Labor Market in Indonesia}

The demographic bonus is a potential support for the supply of human resources in Indonesia. Along with the increase in population from 206.26 million in 2000 and to 237.64 million in 2010, the labour force also increased from 95.65 million in 2000 to 108.21 million in 2010. In 2000 to 2010 , the labour force increased from $46 \%$ to $49 \%$ of the total population. Based on the projection of Indonesia's Statistical Office, the population of Indonesia in 2025 reached 282 million and increased by 296 million in 2030. With the increasing proportion of the labour force, it can be a benefit to Industry 4.0. Fig. 1 shows the development of the number of the Indonesian labour force since 2000.

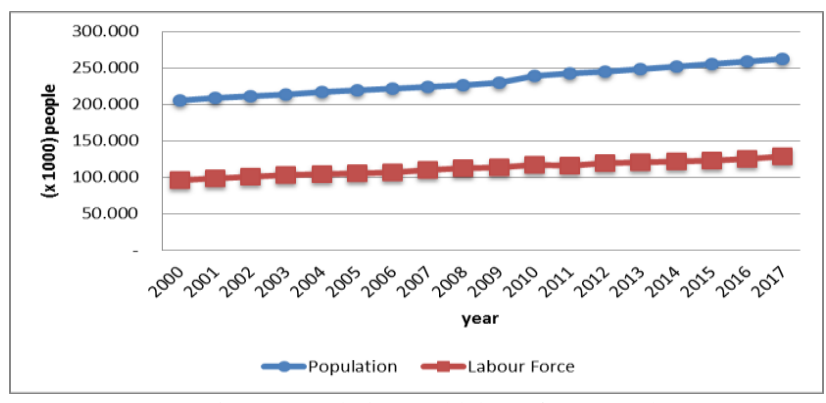

Fig. 1. Population and labour force trend.

The increase in the number of labour force has not been in line with the increase in education level. In 2000, more than $95 \%$ of the workforce were not graduates of diplomas or universities. This improved with an increase of around $12 \%$ of the labour force with diploma and tertiary education in 2017 as shown in Table I. Industry 4.0 requires workers with skills and competencies, both those obtained from formal and non-formal education. The low number of diploma and university graduates shows a lack of readiness to face competitiveness in advancing technology and innovation capacity.

TABLE I: LABOUR FORCE LEVEL OF EDUCATION

\begin{tabular}{|c|c|c|c|c|c|}
\hline & 2000 & 2005 & 2010 & 2015 & 2017 \\
\hline $\begin{array}{l}\text { Below } \\
\text { diploma (D) }\end{array}$ & 91.212 & 99.959 & 107.104 & 108.832 & 112.592 \\
\hline $\begin{array}{l}\text { D share in } \\
\text { labour force }\end{array}$ & $95,4 \%$ & $94,4 \%$ & $91,9 \%$ & $88,9 \%$ & $87,9 \%$ \\
\hline $\begin{array}{l}\text { Diploma/ } \\
\text { University (U) }\end{array}$ & 4.439 & 5.899 & 9.423 & 13.548 & 15.471 \\
\hline $\begin{array}{l}\text { U share in } \\
\text { labour force }\end{array}$ & $4,6 \%$ & $5,6 \%$ & $8,1 \%$ & $11,1 \%$ & $12,1 \%$ \\
\hline
\end{tabular}

(*in thousand people)

Fig. 2 shows selected groups of occupation which considered to be significant driving force of Industry 4.0. Based on the proportion of the workforce on the demand side, workers who enter the market was mostly as the service and sales workers with amounts about $17 \%$ of the labour force anually. While Professionals and Technicians/Associate Professionals, which is more require technical application of skill and competency for advancing technology and innovation, only around $6 \%$ each year.

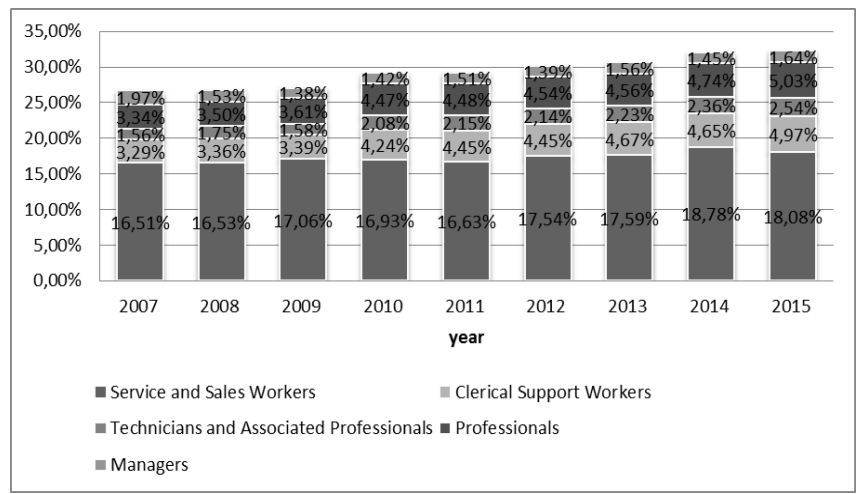

Fig. 2. Percentage of selected occupation to labour force. 


\section{B. HRST and Industry 4.0}

Human resources, which are closely related to the development of science and technology and innovation, regarded as Human Resources in Science and Technology (HRST). The dynamics model of HRST shows that HRST with its competence are interrelated with the mode of technology adoption which then affects performance in economy [9]. This can be a motivation that HRST will play a significant role within technology development and innovation in Industry 4.0.

Table II shows percentage of HRST to worker in Professional and Technician classification of occupation. Refers to current labour market data, HRST Major 2 (Professional) and HRST Major 3 (Technician) made up around $84 \%$ of Professional and Technician workers. Overall, the trend of ratio HRST within workers is declined for years.

\section{TABLE II: HRST TO PROFESSIONAL AND TECHNICIAN}

\begin{tabular}{lcccc}
\hline \hline & 2007 & 2010 & 2013 & Average \\
\hline $\begin{array}{l}\text { (Major 2) } \\
\text { HRST Professional }\end{array}$ & $99,76 \%$ & $99,72 \%$ & $96,79 \%$ & $98,76 \%$ \\
(Major 3) & & & & \\
HRST Technician & $64,10 \%$ & $47,60 \%$ & $47,48 \%$ & $53,06 \%$ \\
HRST P,T & $88,43 \%$ & $83,16 \%$ & $80,56 \%$ & $84,05 \%$ \\
\hline \hline
\end{tabular}

Meanwhile HRST Professionals are about $98 \%$ of professional workers. And HRST Technicians are about 53\% of technician workers. Both, HRST Professional and Technician are declines to each Professional and Technician workers.

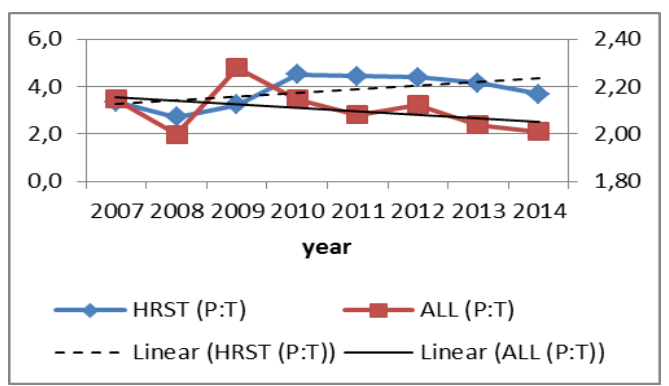

Fig. 3. Ratio of Professional to Technician

Fig. 3 shows the ratio of professional to technician, both for overall worker and HRST. In HRST trend, number of professionals increased more than technicians. On the contrary, in general term, the number of technicians increased more than professionals. The HRST trend match to characteristics of Industry 4.0, which is automation in manufacturing, so that less technicians needed to handle the factory. The increasing number of professionals, and less increase for technicians, are needed to develop technology and innovation.

The less number of worked HRST occurs because of lack in link and match between supply and demand. The increase in supply, higher education graduates in the field of science and technology, was greater than the increase in demand in the labor market [10]. In Industry 4.0, it is possible that the excess supply can be absorbed due to more workers, with high skills and competencies in the field of science and technology, will be needed.

\section{Education to Build Competencies}

A new era of industrial revolution requires workers who have the ability to develop technology and innovate. This might happened if workers have knowledge with skills and competencies correspond with the needs of industry 4.0.

Future work, instead, will be based on adaptive workforces organized around projects, supported by embedded training. This new kind of employee needs a different kind of education in preparation. In preparing lifelong learners, Gleason suggests Problem-based learning and project-based learning in education with three main thrusts, i.e. digitally literate, technologically competent and build initiatives [11]. In terms of qualification level, demands of the academic field gains, the majority of losses occur in the field of vocational training. Also the demand for low-qualified work decreases [12].

Education 4.0 is a term has been the starting point to the education system for a reshuffle, to fulfill workforce requirements of the talent needed that will be changed. Education 4.0 is predicted to be the new era of combining technology into almost every elements in pedagogy education. Students or learners are expected to innovate and somehow a source of knowledge and the learning process can be done everywhere and whenever [13].

To be able to see the potential supply of higher education, we explore the trend of higher education graduates, including diploma and university levels.

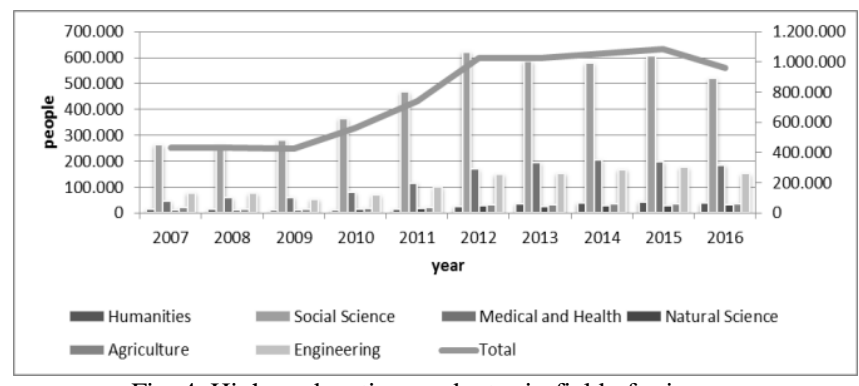

Fig. 4. Higher education graduates in field of sciences.

Graduates of higher education based on the classification of fields of science used by the OECD consist of 6 fields, namely humanities, agriculture, social science, medical and health, natural science, and engineering [14]. Fig. 4 shows that there is an increase in the graduates, which means increasing labor supply. But seen from the field of science is still not balanced, engineering and natural science are still much lower than social science.

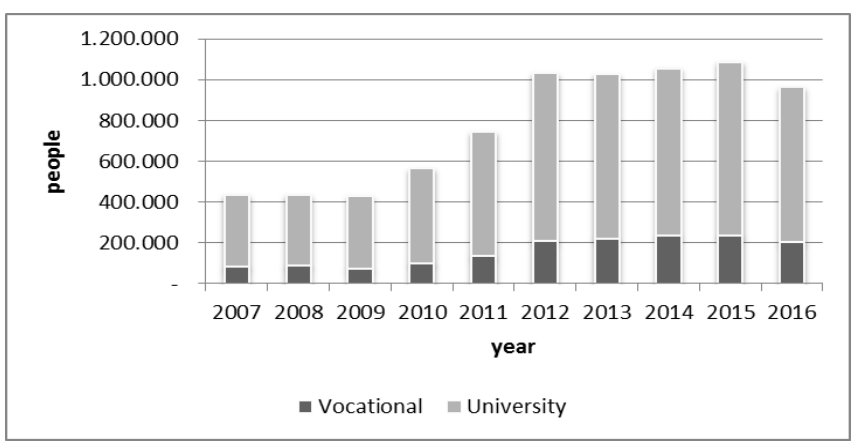

Fig. 5. Graduates from vocational education and university. 
Higher education graduates are dominated by bachelor degree and above as in Fig. 5. The period of study for a university normally taken at least in 4 years. While vocational education study period is shorter, between 1 and 4 years. The number of vocational education graduates is still low due to the lack of organizing institutions plus a lack of interest in participating in vocational education (diploma/polytechnic).

Education is one way to build competence. The government through the Ministry of Research, Technology and Higher Education has been working on various steps to improve the quality of human resources in Indonesia in the face of industry 4.0, which is expected to be a force to have global competitiveness. One of the main steps is to reorient the curriculum, namely to develop new methods in teaching by providing a focus on data, technology, and humanities, complemented by extra curricular activities in order to develop the leadership skills and teamwork, and to build entrepreneurship and internship is compulsory. The government also recommends higher education for Establishing Life-long Learning units. To expand coverage, education is also carried out through on-line learning systems by pioneering SPADAIdREN. The government also provides grants and technical services for curriculum reorientation (GEN-RI 4.0) for 400 universities. Along with infrastructure development, i.e. the development of Teaching Industry, the building of e-library infrastructure, the development of the Massive Open Online Course (MOOC) infrastructure, and the development of the Science and Innovation Museum. The various policies mentioned earlier complement the previous policies that have been carried out to build Indonesia's human resources competencies in science and technology field, including the moratorium on non-STEM higher education, improvement of vocational education, and the establishment of national standards for qualification of workers (Indonesian National Qualification Framework, KKNI).

We can see the professional and technician position and level of education from national workforce survey data. Fig. 6 describes the proportion of professional and technical positions with certain higher education backgrounds. In general, higher education graduates show an increasing trend, from $64 \%$ to $69 \%$. The largest proportion is undergraduate level, which is around 45\%. Diploma level are around 16\% with decreasing trend. While graduate level are only around $5 \%$, but with the increasing trend. Diploma includes 1 to 3 years of study, undergraduate includes 4 years diploma and bachelor degree, while graduate includes master degree and doctoral degree.

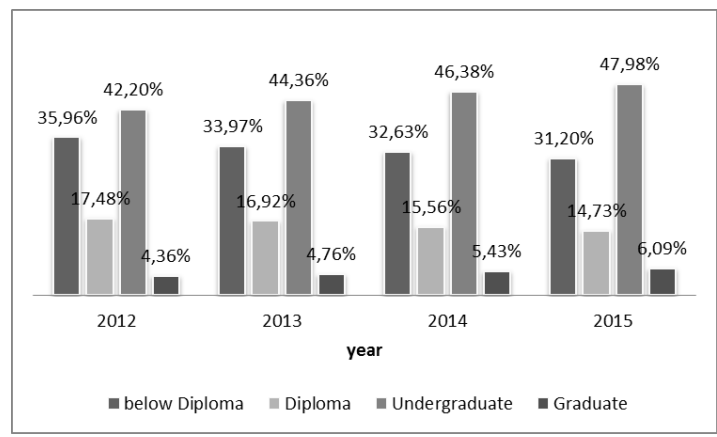

Fig. 6. Professionals and technicians based on education level.
The loss of various types of work (and skills) and the emergence of new jobs (and skills) in Industry 4.0 is a challenge for vocational education to be able to produce graduates who are able to enter the rapidly changing world of work. The government also needs to encourage the development of vocational education to create a supply of human resources that meets industrial needs. In the Indonesian context, it includes vocational high school and polytechnics/diploma programs. Indonesia with unique geographical conditions and diverse economic potentials, vocational education is encouraged to be developed in accordance with the economic potential of each region, commodity-based vocational education development (CBVED)[15]. So that graduates can more quickly enter the workforce and the industry will not lack the workforce as needed.

\section{DISCUSSION AND CONCLUSION}

Indonesia as many other countries facing a new era of Industry 4.0. Industry 4.0 has different characteristics from the previous industrial era, especially marked by the development of the application of technology in the industry, namely the Cyber Physical System and the Internet of Things. To deal with the challenges that come with it, it is necessary to describe the strengths and weaknesses we have. Human resources are one of the important aspects in industry 4.0, with role as creators and users of technology in the industry. Indonesia with abundant human resources in the demographic bonus period, might take advantages of human resources as a capital in facing the competition in industry 4.0. This study was conducted to capture the potential of human resources, in general as workforce. Furthermore we see human resources from two sides, demand side in industry and education as the supply side to the industry.

Currently the implementation of Industry 4.0 in Indonesia is still not significant progress. The production process still has not shifted to the method used in Industry 4.0, this can be seen with no new form of employment structure. The proportion of professionals and technicians is still low. Similarly, when viewed from the proportion of HRST. This corresponds to the number of workers with higher education qualifications, which still low.

Higher education as one way to build the competency of prospective workers. Indonesia's data trends show an increase in the number of tertiary education graduates, both vocational and university education. The government has made various efforts to increase the quantity and quality of higher education graduates as mentioned above. By the educational background of professional workers and technicians shows the declining trend of vocational education graduates and increasing of university graduates in industry.

In conclusion, by observing the trend, the potential of the labour force to support the implementation of Industry 4.0 is good in terms of quantity in supply, not in quality. To be able to improve capability and competitiveness in Industry 4.0, there is still need improvement in term of quality of the workforce, especially by improving the quality of education. 
Vocational education programs being developed by the government along with the direction of preparation towards Industry 4.0. In line with that, Learning Factory needs to be developed to increase competence. Learning factories, the linking of learning strategies and latest trend in manufacturing, are a promising approach to competency development [16]. The government also needs to ensure the link and match between supply from education and demand in the labor market. Further research needs to be developed to determine the right method of creating workforce, that has skills and competencies, which is in line with demand of Industry 4.0.

\section{REFERENCES}

[1] B. Slusarczyk, "Industry 4.0 - Are we ready?" Polish Journal of Management Studies, 2018.

[2] S. Kergroach, "Industry 4.0: New challenges and opportunities for thr labour market," Foresight and STI Governance, vol. 11, no. 4, 2017.

[3] B. Paul and J. D. Roux, "Industry 4.0: Preparing for the future of work," People +Strategy, vol. 40, no. 3, 2017.

[4] Ministry of Industry, Making Indonesia 4.0, 2018.

[5] V. Tomas and N. Martina, "Labour market in the context of industry 4.0," in Porc. the 11th International Days of Statistics and Economics, Prague, September 14-16, 2-17.

[6] Manual on the Measurement of Human Resources Devoted to S\&T Canberra Manual. [Online]. Available: http://www.oecd-ilibrary.org/science-and-technology/measurement-of -scientific-and-technological-activities_9789264065581-en

[7] A. Laudeline and S. Jerry, "Human resources in science and technology measurement issues and international mobility," OECD, 2001.

[8] I. J. Asmara, E. Achelia, M. Akbar, R. Rahmaida, and M. Arifin, "Indonesia's national HRST scenario 2025 in research report, center of science and technology development studies," Indonesian Institute of Sciences, 2015.

[9] A. Elmi and A. J. Indri, and A. Maulana, and G. B. Nani, and T. Muhammad, "STEM competency to support technology Advancement and national HRST performance," International Journal of Social Science and Humanity, vol. 8, no. 6, pp. 178-185, 2018.

[10] J. A. Indri and A. Elmi, A. Maulana, and T. Muhammad, "Linking supply on demand of Indonesia human resource in science and technology on perspectivve black swan phenomenon," in Porc. the Asian Conference on Education \& International Development 2017, March 26-29, 2017.

[11] N. W. Gleason, Singapore's Higher Education Systems in the Era of the Fourth Industrial Revolution: Preparing Lifelong Learners, 2018.

[12] E. Weber, Industry 4.0 - Job-Producer or Employment-Destroyer? 2016.

[13] M. Maria, F. Shahbodin, and N. C. Pee, "Malaysian higher education system towards industry 4.0 - Current trends overview," AIP Conference Proceedings, 2016.

[14] OECD. 2007. Revised Field Of Science And Technology (FOS) Classification In The Frascati Manual. [Online]. Available: https://unstats.un.org/unsd/EconStatKB/KnowledgebaseArticle10269. aspx

[15] M. Samani, "Vocational education in the era of industry 4.0: An Indonesian case," Advances in Social Science, Education and Humanities Research (ASSEHR), vol. 201, 2018.

[16] B. Felipe, G. Alvaro, M. Julian, S. Joel, and R. Sebastian, "Learning factory: The path to industry 4.0," in Porc. the 7th Conference on Learning Factories, CLF 2017, Procedia Manufacturing, 2017.

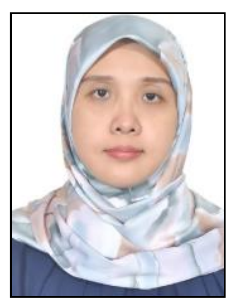

EImi Achelia was born on Jakarta in 1984. She received her bachelor in computer science from IPB on 2005 and the magister in information technology from University of Indonesia in 2012.

Elmi is a researcher in Center of Science and Technology Development Studies, Indonesia Institute of Science (LIPI). Joined with LIPI since 2006. Currently focus in science and technology policy research, specifically in forecasting science and technology resources using System Dynamics method. Also interested in research at field of computer science and information technology, as well as previous research field in data mining and big data visualization.

Her latest article in International Journal of Social Science and Humanity vol. 7, no. 6, pp. 494-500 titled "The Impact of Education on National HRST Performance" published in 2017; International Journal of Social Science and Humanity vol. 8, no.6, pp. 178-185 titled "STEM Competency to Support Technology Advancement and National HRST Performance" published in 2018; and Proceeding of ACEID 2017 titled "Linking the Supply on Demand of Indonesia Human Resource in Science and Technology on the Black Swan Phenomenon Perspective" published in 2017.

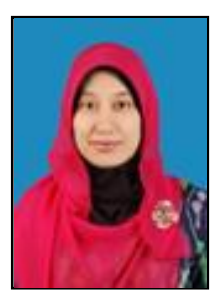

Indri J Asmara was born in Medan Indonesia, January $4^{\text {th }}$ 1981. She got the bachelor degree in computer science in 2002 and the master degree in information technology in 2012 at University of Indonesia, Jakarta, Indonesia.

She is a researcher in Center for S\&T Development Studies at Indonesian Institute of Sciences in Jakarta, Indonesia. The field of study is S\&T management and S\&T Policy.

She has several publication such as (1) Technological Capability Upgrading and Entrepreneurship: Case Study of Selected Indonesian Fish Processing Companies published on STIPM Vol.1 No.1/July/2016. ISSN: 2540-9786, (2) Technological Convergence in Indonesian Firms: Cases of Biobased Chemical Product Innovation published on ASIAN Journal of Technology Innovation, and published online on June $25^{\text {th }} 2015$, DOI: 10.1080/19761597.2015.1011259, (3) Linking the Supply on Demand of Indonesia Human Resource in Science and Technology on the Black Swan Phenomenon Perspective published on ACEID2017 proceeding. The past two years she has been done research about Human Resource that devoted on S\&T in Indonesia.

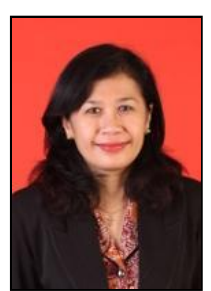

Nani Grace Berliana was born in Jakarta on October 24, 1966. She first earned a bachelor's degree, majoring in mathematics at University of Indonesia - Indonesia, in 1985. Second, She got the master degree on women studies at University of Indonesia in 1998.

She has worked for more than 20 years at Research Center for Development of Science and Technology Indonesian Institute of Sciences.

She was a head of Sub Division of Research Cooperation on 2000 until 2002; head of sub-field of Measurement and Science and Technology Parameters on 2002 until 2010; Head of Information Systems and Management of Science and Technology on 2011 until 2014 and Head of Research and Dissemination Research Division on 2014 until 2017. Since 2002 to date, she is a researcher in business R \& D and innovation, conducting measurement or R \& D and innovation. During the last four years doing research on the modeling of Science and Technology Human Resource.

Dra. Nani Grace Simamora, M. Hum has some scientific publications include Indonesian S\&T Indicators, Jakarta, LIPI Press, 2015; The Atlas of Islamic World Science and Innovation country Case Study Indonesia, Turki, OIC, 2014. Science and Technology in Indonesia-in Brief, Jakarta Pappiptek, 2014. Study on the Status Science \& Technology Development in Indonesia, 2012. PAPPIPTEK-LIPI; Study on Implementation and Utilization of Mini / Micro Hydro Power Plants (PLTMH) for Increasing Productive Enterprises of Rural Communities, LIPI Press, 2010. 